\title{
The genus Spondylosium Brebisson ex Kützing in waterbodies of West Siberia (Russia)
}

\author{
Yuri $V$. Naumenko ${ }^{1 *}$ \\ ${ }^{1}$ Central Siberian Botanical Garden of the Siberian Branch of the Russian Academy of Sciences, 101 \\ Zolotodolinskaya Str., Novosibirsk, 630090, Russia
}

\begin{abstract}
The article generalizes data on the species diversity of the genus Spondylosium Brebisson ex Kützing representatives in waterbodies of West Siberia, their distribution over zones and subzones. At present, 8 species and intraspecific taxa of the order Desmidiales are known in the region. These family representatives are mosaic spread throughout the territory of West Siberia. The largest numbers of taxa (5) are found in middle taiga, 1 and 3 taxa - in southern and northern taiga, respectively, from 2 to 4 taxa - in other zones. No species is recorded in the steppe zone. 6 species (7 taxa) of this genus are identified in lakes of diverse types, 4 species are known in streams, 2 species - in mires and temporary waterbodies. The analysis of the species confinement to environmental conditions has shown that the genus representatives can serve as indicators of acidic and slightly mineralized water. Indifferents (6 taxa) predominate as mineralization indicators, acidophiles (6 taxa) prevail among $\mathrm{pH}$ indicators.
\end{abstract}

\section{Introduction}

The genus Spondylosium Brebisson ex Kützing was described by L. A. Brebisson, a French naturalist, in 1844; its systematic position was clarified by F. Kützing in 1849 . The genus species are distinguished from other genera of the order Desmidiales (family Desmidiaceae) by their peculiar cell structure. The cells are linked into long threads by apices directly, or with the help of mucous pads. The cells are small, compressed, deeply laced, oval, triangular or three-lobed. The semi-cells are oval, pyramidal or quadrangular, often with a widely cut or concave tip. The cell wall is smooth or granulated. It is known that these genus representatives are frequently found in waterbodies with low $\mathrm{pH}$, low water temperature and poor mineral and biogenic substances. Due to insufficient knowledge of the genus species diversity in different continents, information on their ecology and distribution is extremely important.

The first mention on this genus record in waterbodies of West Siberia was made by B.V. Skvortsov [1]. Spondylosium planum (Wolle) W. et G.S. West was marked in lakes of the Altai mountain (species' authors see Table 1). The information reservation on these

* Corresponding author: naumenko55@ngs.ru 
species diversity in West Siberian flora was slow. Findings were recorded during hydrobiological and floristic studies in various natural zones. Special systematic studies of this group of organisms were not carried out. There is a limited number of publications on representatives of this genus, some of them are bibliographic rarities.

The number of taxa in the waterbodies of the studied region totals 8 species and intraspecific taxa after field research in the Natural Park "Siberian Ridges [Sibirskie Uvaly]" located in the mid taiga subzone, and taking into account literature data.

The paper presents study results of spreading Spondylosium in various zones of West Siberia in the Russian Federation frames and their ecological characteristics.

The work objective is to summarize information on the genus representatives living in waterbodies of West Siberia.

\section{Materials and Methods}

Phytoplankton, periphyton and phytobenthos field gathering were carried out in Natural Park "Siberian Ridges" in 2009-2011 at two key sites in the southern part of the protected area. Floodplain and continental lakes, streams and tributaries of the Gluboky Sabun River have been studied. Algological sample collecting and measuring water temperature, $\mathrm{pH}$, and transparency were concurrent. The material was examined with light microscope "Amplival" at 16 x 40 magnification. Desmidiaceae species were determined using the appropriate keys [2-4]. The article materials were literature and original data on the algae of West Siberian waterbodies. A whole list of references is not presented in the article as it is quite extensive.

\section{Results and Discussion}

Four species (Spondylosium planum, S. pulchellum, S. pygmaeum, S. pulchrum) were revealed after field study in middle taiga, Natural Park "Siberian Ridges". The latter species was presented for the first time for waterbodies in West Siberia.

All species of the genus were recorded in the Natural Park at $6-19^{\circ} \mathrm{C}$ water temperatures, the largest number of taxa were found at $16-19^{\circ} \mathrm{C}$. The genus representatives were found at water transparency of $0.16-0.46 \mathrm{~m}$, the largest number of them was noted in 0.22 to $0.35 \mathrm{~m}$ range.

The genus Spondylosium species vegetated at $\mathrm{pH}=4.7-6.6$, the greatest species diversity was noted at $\mathrm{pH}=4.7-5.5$. The greatest variety of Desmidiaceae was marked at acidic values of the environment active reaction by literature data $[2,3]$.

Nowadays, 7 species have been recorded represented by 8 species and intraspecific taxa in all waterbodies of the region under study.

Table 1. Distribution of Spondylosum species in natural areas of Western Siberia and their ecological and geographical characteristics

\begin{tabular}{|l|l|l|l|l|l|l|l|l|l|l|l|l|l|l|}
\hline Species & O & ПО & T & FT & ST & SRT & UT & FS & MS & M & GL & A & S & G \\
\hline $\begin{array}{l}\text { Spondylosium } \\
\text { papillosum } \\
\text { W. et G.S. } \\
\text { West }\end{array}$ & + & - & - & + & + & - & - & + & + & p & hb & az & $?$ & k \\
\hline $\begin{array}{l}\text { S. planum } \\
\text { (Wolle) W. et } \\
\text { G.S. West }\end{array}$ & + & + & + & + & + & + & + & - & + & p & i & i & $\beta$ & aa \\
\hline
\end{tabular}




\begin{tabular}{|l|l|l|l|l|l|l|l|l|l|l|l|l|l|l|}
\hline $\begin{array}{l}\text { S. pulchellum } \\
\text { Archer }\end{array}$ & - & - & + & - & + & + & - & + & + & $\mathrm{p}$ & $\mathrm{i}$ & $\mathrm{az}$ & $\mathrm{o}$ & $\mathrm{k}$ \\
\hline $\begin{array}{l}\text { S. pulchrum } \\
\text { (Bail.) Archer }\end{array}$ & - & - & - & - & - & + & - & - & - & $\mathrm{p}$ & $\mathrm{i}$ & $\mathrm{az}$ & $?$ & $?$ \\
\hline $\begin{array}{l}\text { S. pygmaeum } \\
\text { (Cooke) West } \\
\text { var. } \\
\text { pygmaeum }\end{array}$ & - & - & - & - & - & + & - & - & - & $\mathrm{p}$ & $\mathrm{i}$ & $\mathrm{az}$ & $?$ & $\mathrm{~b}$ \\
\hline $\begin{array}{l}\text { S. pygmaeum } \\
\text { var. } \\
\text { compressum } \\
\text { West }\end{array}$ & - & - & - & - & - & - & - & - & + & $\mathrm{p}$ & $\mathrm{i}$ & $\mathrm{az}$ & $?$ & $\mathrm{~b}$ \\
\hline $\begin{array}{l}\text { S. sedecens } \\
\text { (De Be Bary) } \\
\text { Archer }\end{array}$ & - & - & + & - & - & - & - & - & - & $\mathrm{p}$ & $\mathrm{i}$ & $\mathrm{az}$ & $\mathrm{z}$ & $\mathrm{k}$ \\
\hline $\begin{array}{l}\text { S. tetragonum } \\
\text { W. et G.S. } \\
\text { West }\end{array}$ & - & - & - & - & - & + & - & - & - & $\mathrm{p}$ & $?$ & $?$ & $?$ & $?$ \\
\hline
\end{tabular}

Note: "+ "- the view is present, " - " - the view is absent. On the Ob, IN the floodplain of the Ob, Ttundra, FT- tundra, ST - Northern taiga, SRT - middle taiga, UT - South taiga, FS - forest-steppe, MS - mountain, M - habitat, $\mathrm{p}$ - plankton, GL - globest, hb - halophob, i - indifferent, A acidophiles, az - acidofil, $\mathrm{i}$ - indifferent, $\mathrm{S}$ - saprobiont, o - oligosaprobic, $\beta$ - betamethasaprobic, geo - geographical distribution, $\mathrm{k}$ - cosmopolitan, aa - arctoalpine, $\mathrm{b}$ - boreal, ? - little studied in ecological and geographic terms look.

No common species marked in all zones and subzones are found, it can be explained by the insufficient knowledge on the studied region. The genus representatives are mosaic spread throughout the territory of West Siberia. 5 species (the largest number) is identified in middle taiga, 4 - in mountain waterbodies, 3 - in tundra, northern taiga and mountains. No species are found in steppe.

Such species as Spondylosium planum, S. papillosum, S. pulchellum were more common than others. When moving southward, the number of species decreases in foreststeppe and steppe zones, where there is a significant number of slightly saline and salty waterbodies. Spondylosium genus species are found in diverse waterbodies, but the species number in a particular waterbody or stream varies from 1 to 2 .

In total, 7 species and intraspecific taxa have been identified in diverse lakes of West Siberia. Spondylosium planum and S. pulchellum are the most common, S. papillosum is less common. Other taxa have been revealed once. At present, two representatives of this genus have one location in waterbodies of the studied region. Spondylosium sedecens is marked in a tundra lake [5], and $S$. pygmaeum var. compressum is recorded in fouling of Lake Azhendarovskoe, the Kuznetsk Hollow [6].

Four species have been found in waterways, including the Ob and Irtysh Rivers. Only two species are identified in the Ob River: Spondylosium planum, S. papillosum, and not a single species - in the Irtysh River. It should be noted that Spondylosium sp. is marked in phytoplankton and fouling of the Irtysh River near Omsk city [7,8]. Spondylosium planum is revealed in the lower Ob River floodplain [9].

Mires cover vast areas in West Siberia, but there is no work devoted to these unique reservoirs at present. Two species (Spondylosium planum and S. pulchellum) are identified in wetlands, as well as in temporary waterbodies.

No species of this genus have been found in ponds in Western Siberia.

The genus representatives are characterized with wide ecological amplitude. According to our and published data, more often species are found in waterbodies in plankton (Tabl. 2), periphyton, and bottom samples as well. 
Table 2. Ecological and geographical characteristics of algae Spondylosium genus in water bodies of Western Siberia

\begin{tabular}{|c|c|c|}
\hline Ecological and geographical group & Number of taxa & $\%$ of detected taxa \\
\hline \multicolumn{3}{|l|}{ Habitat } \\
\hline $\mathrm{p}$ & 32 & 55.2 \\
\hline \multicolumn{3}{|l|}{ Relation to $\mathrm{NaCl}$} \\
\hline $\mathrm{hb}$ & 1 & 12.5 \\
\hline $\mathrm{i}$ & 6 & 75.0 \\
\hline$?$ & 1 & 12.5 \\
\hline \multicolumn{3}{|l|}{ Relation to $\mathrm{pH}$} \\
\hline $\mathrm{az}$ & 6 & 75.0 \\
\hline $\mathrm{i}$ & 1 & 12.5 \\
\hline$?$ & 1 & 12.5 \\
\hline \multicolumn{3}{|l|}{ Saprobity } \\
\hline o & 1 & 12.5 \\
\hline$\beta$ & 2 & 25.0 \\
\hline$?$ & 5 & 62.5 \\
\hline \multicolumn{3}{|l|}{ Geographical characteristic } \\
\hline $\mathrm{k}$ & 3 & 37.5 \\
\hline $\mathrm{b}$ & 1 & 12.5 \\
\hline aa & 1 & 12.5 \\
\hline$?$ & 3 & 37.5 \\
\hline
\end{tabular}

Note: the designation is the same as in table 1.

The species were observed from the second decade of June to late September in all waterbodies. Most taxa were recorded in July-August. During the whole observation period, the species were found in $5.9-27.0^{\circ} \mathrm{C}$ temperature range. The most representatives of the genus were observed at $14.7-18.4^{\circ} \mathrm{C}$ temperatures. S. pygmaeum var. compressum was once recorded in the lake at a temperature of $27.0^{\circ} \mathrm{C}$ [6]. According to available data on water transparency, it varied in $0.16-3.50 \mathrm{~m}$ frames, but the largest number of species was noted at $0.16-0.35 \mathrm{~m}$ range.

Species of the genus Spondylosium vegetate at $\mathrm{pH}$ equal to 4.5-7.2. The most taxa were noted at 5.3-6.8 $\mathrm{pH}$ values. The general ecological characteristics of the genus representatives indicate the acidic environment preference to vegetate the species. The most common species, Spondylosium planum, was recorded in waterbodies of West Siberia at 5.27-7.21 $\mathrm{pH}$ frames. This species vegetates at $\mathrm{pH}=8.5$ in Lake Gaevskoe (swampy shores), Valday National Park, Novgorod Region [10].

There is not enough information on algae ecological and geographic characteristics. All identified species are planktonic organisms. In relation to salinity, most of them are oligohalobes, among them 6 species are indifferent, and one - a halophobe. Data on $\mathrm{pH}$ frames for this or that species are known for 7 taxa, 6 of which are acidophiles occurring at $\mathrm{pH}<7$, one species is indifferent. There is low information on saprobic characteristics. Biogeographically, 3 taxa are widespread in the world waterbodies (Table 3).

Table 3. The study of Spondylosium representatives in some flora of Russia and abroad

\begin{tabular}{|l|l|l|l|l|l|l|}
\hline Number & WS & Y (1) & FF (2) & U (3) & R (4) & I (5) \\
\hline species & 7 & 3 & 7 & 8 & 3 & 11 \\
\hline species, variety, form & 8 & 3 & 7 & 9 & 3 & 12 \\
\hline
\end{tabular}

Note: WS - Western Siberia, Y -Yakutia, FF - Far East, U - Ukraine, R - Romania, I - Ireland, 1 [12], $2-[13], 3-[3], 4-[15], 5-[16]$ 
Comparing the taxa diversity of the genus Spondylosium in West Siberia and floras in Russia and abroad has shown that the study level of these organisms is quite comparable to that in Russia, but inferior to Irish and Ukrainian ones. However, a thorough study of waterbodies in the Barguzin Reserve made it possible to identify 4 species of this genus [11]. Task-specified research of waterways and reservoirs in different zones of West Siberia will allow revealing the biological diversity of this territory.

Thus, the analysis and generalization of the original and published data has shown that at present 7 species of the genus Spondylosium are known in waterbodies of West Siberia, represented by 8 species and intraspecific taxa. The largest number of this genus representatives is noted in diverse lakes. Tundra, forest-tundra, northern and southern taiga, forest-steppe, steppe, and mountains remain the least studied natural zones of West Siberia as regarded to the genus. Oligoghalobes prevail in relation to water mineralization, where indifferent species are $75.0 \%$. As to environ $\mathrm{pH}$, acidophiles are the most numerous $(75.0 \%)$. The most taxa are found in waterbodies at plains of the study area.

\section{References}

1. B. W. Skvortzow, J. of Bot., 69 (1931)

2. C. Kossinskaja, Flora of spore plants of the USSR (Moscow, USSR Academy of Sciences, 1960)

3. G.M. Palamar-Mordvintseva, G. M. Palamar-Mordvintseva, Flora of water courses of continental waters of Ukraine: DesmịdcBsvị vodorostị (Kiev, 2005) In Ukr.

4. P.F.M. Coesel, K. J. Meesters, Desmids of the Lowlands Mesotaeniaceae and Desmidaceae of the European Lowlands. (Zeist, 2007)

5. Y.V. Naumenko, L.A. Semenova, News of systematics of lower plants, 31 (1996) In Russ.

6. O.V. Tulchinskaya, T.A. Safonova, Probl. of Ecol., 10 (2003) In Russ.

7. A.P. Skabichevsky, Phytoplankton, in Sanitary characteristics of the Irtysh river in the Omsk region according to physical, chemical, bacteriological and biological studies, (Omsk. med. in-t, 1957) In Russ.

8. L.D. Chistyakov, Periphyton in Sanitary characteristics of the Irtysh river in the Omsk region according to physical, chemical, bacteriological and biological studies (Omsk. med. in-t, 1957) In Russ.

9. T.A. Safonova, Algae and fungi of Western Siberia (Novosibirsk, Nauka, 1964) In Russ.

10. A.F. Luknitskaya, News of systematics of lower plants, 51(2017) In Russ.

11. A.B. Bochka, Algae in Flora and fauna of reservoirs and watercourses of the Barguzinsky reserve (Moscow, 2000) In Russ.

12. Diversity of the plant world of Yakutia (Novosibirsk, 2005) In Russ.

13. L. A. Medvedeva T. V. Nikulina, Catalog of freshwater algae of the South of the Russian Far East (Vladivostok, 2014) In Russ.

14. I. Caraus Algae of Romania (a distribution checklist of actual algae) (Ver. 2.3., Bacaŭ, 2012)

15. D. M. John, D.B. Williamson, M. B. Guiry, A catalogue of the Desmids (Streptophycophyta, Zygnematophyceae, Zygnematales) of Ireland (Dublin, 2011) 